[CONTRIBUTION FROM THE LABORATORIES OF THE ROCKEFEILER INSTITUTE FOR MEDICAL RHSEARCH.]

\title{
AROMATIC ARSENIC COMPOUNDS. X. AZO DYES DE- RIVED FROM ARSANILIC ACID.
}

By Walter A. JacoBs AND Michael Heidel, BERGER.

Received June 29, 1920.

As stated in the previous paper, azo dyes containing arsenic were first described by Ehrlich and Bertheim ${ }^{1}$ and later by Barrowcliff, Pyman, and Remfry, ${ }^{2}$ and others. In our work with diazo-amino derivatives it was found that certain classes of aromatic amino compounds yielded amino-azo dyes at once when used as couplers with diazotized arsanilic acid, or gave diazo-amino compounds which rapidly rearranged into the dyes. This occurred with $N$-alkyl anthranilic acids, $m$-amino-phenoxyacetic acid and its substitution products, the amino-veratric acids, and the $o$-methyl and $o$-alkoxy derivatives of $N$-phenylglycine.

As far as we can find, no mention has been made of the use of $N$-alkylanthranilic acids for the synthesis of azo dyes. The addition of $N$-methyl anthranilic acid to the neutralized diazo solution results in the rapid formation first of the diazo-amino compound, which slowly rearranges to the dye on standing or changes over rapidly on acidification with acetic acid. A similar behavior was noted with $N$-ethyl- and $N$-iso-amylanthranilic acids.

Under the usual conditions of coupling in neutral or slightly acid solution, $m$-amino-phenoxyacetic acid yielded at once a dye in which we assume the azo group to enter the position para to the amino group. We believe that $m$-amino-phenoxyacetic acid functions here as a $m$ anisidine derivative as we have since noted the analogous experience of Reverdin, Rilliet and Vernei, ${ }^{3}$ in which $p$-amino-azo dyes were prepared from $m$-phenetidine. Azo derivatives were also obtained by us from two groups of substitution products of $m$-anisidine and $m$-aminophenoxyacetic acid, in one of which the position para to the amino group was free, and in the other of which this position was occupied by a substituent. In the former group were 4-methyl-5-amino-phenoxyacetic acid and 2-amino-3,4-dimethoxy-benzoic acid, and in these cases the azo group presumably entered the free para position. In the second group were 2-methyl-5-amino-phenoxyacetic acid, 3-amino-6-methoxy-phenoxy acetic acid, 6-amino-o-veratric acid, 4-amino-6-methoxy-phenoxy-acetic acid, and amino-o-phenylene-di (oxyacetic acid); and in this group it is probable that the azo group enters the position ortho to the amino group. Thus German patent 230,592 describes the formation of $o$-amino-azo dyes

${ }^{1}$ Ehrlich and Bertheim, Ber., 40, 3292 (1907).

2 Barrowcliff, Pyman and Remfry, J. Chem. Soc., 93, 1893 (1908).

${ }^{3}$ C. A., 13, 312 (1919). 
from 2-methyl-5-amino-phenoxyacetic acid and from the analogous 2-methyl-5-amino-anisole, and our experience has confirmed the ready formation of azo dyes from such substances.

Finally, although phenylglycine yields principally a diazo-amino compoind under the conditions described in the preceding paper, the $o$-methyl, 0 -methoxy, and o-ethoxyphenyl glycines at once form dyes. According to $\mathrm{Mai}^{4}{ }^{4}$ however, when phenylglycine was coupled in a solution acid to congo red it yielded dyes with diazotized aniline and sulfanilic acid.

In most cases the reaction between the diazotized arsanilic acid and the coupler proceeded smoothly, with very little gas evolution. The isolation and purification of the resulting dyes often presented considerable difficulty, and much experimentation was necessary in order to discover the best conditions for the coupling and whether any dye were best isolated as the free acid, the monosodium salt, or the disodium salt. Hence the manipulative details are quite voluminous, and in order to save space it is deemed best to present the work in abstract form.

The monosodium salts of the dyes were generally very sparingly soluble in water, while the disodium salts dissolved easily. Even very dilute solutions of the latter gave immediate amorphous precipitates with salts of the heavier metals, while their behavior varied toward salts of the alkaline earths.

\section{Experimental.}

To avoid constant repetition it may be stated here that the diazotization of arsanilic acid was carried out under the conditions given in the preceding paper in 2 mols. of normal hydrochloric acid with $5 \mathrm{~N}$ sodium nitrite. Since most of the amino acids were coupled under the conditions necessary for the formation of the monosodium salts of the resulting dyes, it will be understood unless otherwise stated that the diazo solution was first treated with one mol. of $N$ sodium hydroxide solution, the solution thus containing diazobenzene arsonic acid and no free mineral acid. This solution was then slowly treated, with continued turbining and chilling, with a solution of the amino acid dissolved in one mol. of $N$ sodium hydroxide solution, or treated with an additional mol. of alkali and then with a solution of the coupler hydrochloride in the case of basic couplers. Such a procedure will be indicated by the expression B $\rightarrow$ A. Cases in which the diazo solution was added to the coupler are designated by $A \rightarrow B$. Variations from this procedure will be described as they occur.

The values given for water of crystallization were determined on the substances after they had come to equilibrium in the air.

' Mai, Ber., 35, 580 (1902). 


\section{(A) Dyes Derived from Arsanilic Acid and Methoxy-naphthylamines.}

1-Amino-2-methoxy-naphthalene-4'-azobenzene-4'-arsonic acid. $-\mathrm{B} \longrightarrow \mathrm{A}$, using $\beta$-methox $y$ - $\alpha$-naphthylamine hydrochloride. The neamorphous acid was converted into the salt with just enough dil. sodium hydroxide solution. After salting out, dissolving in $50 \%$ alcohol, heating, and making just acid to congo red with hydrochloric acid, the arsonic acid slowly separated on rubbing and cooling as radiating aggregates of narrow, bluish-black, glistening, microscopic platelets, which did not melt below $285^{\circ}$. It dissolves in conc. sulfuric acid with a deep purple color and in dil. sodium hydroxide solution with a deep cherry-red tint.

Analyses. Calc. for $\mathrm{C}_{17} \mathrm{H}_{16} \mathrm{O}_{4} \mathrm{~N}_{3} \mathrm{As} .1 .5 \mathrm{H}_{2} \mathrm{O}: \mathrm{H}_{2} \mathrm{O}, 6.3$. Found: 5.9.

Calc. for $\mathrm{C}_{17} \mathrm{H}_{16} \mathrm{O}_{4} \mathrm{~N}_{3} \mathrm{As}$ : N, 10.48; As, 18.68. Found: N, 10.42; As, 18.50.

1-Amino-4-methoxy-naphthalene-2-azobenzene-4'-arsonic acid.-Obtained like the preceding compound, the arsonic acid separated rapidly as dark brown, microcrystalline aggregates with a bronzy luster. It sintered and darkened when heated, softening to a tar at about $195^{\circ}$ and intumescing at about $225^{\circ}$. It dissolves in conc. sulfuric acid with a purplish-red color, changing to brown-red, and becoming purplish again on dilution. In dil. sodium hydroxide solution the color is a deep cherry-red. It is soluble in acetic acid and alcohol.

Analyses. Calc. for $\mathrm{C}_{17} \mathrm{H}_{16} \mathrm{O}_{4} \mathrm{~N}_{3}$ As. $1.5 \mathrm{H}_{2} \mathrm{O}: \mathrm{H}_{2} \mathrm{O}, 6.3$. Found: 6.0.

Calc. for $\mathrm{C}_{17} \mathrm{H}_{16} \mathrm{O}_{4} \mathrm{~N}_{3} \mathrm{As}$ : N, 10.48; As, 18.68. Found: $\mathrm{N}, 10.31$; As, 18.83 .

\section{(B) Dyes Obtained from Arsanilic Acid and Substituted Amino- benzoic Acids.}

4 - Methylamino - 5 - carbory-phenylazo-benzene-4'-arsonic acid.-B (methylanthranilic acid) $\rightarrow A+$ equal volume saturated sodium acetate solution. The orange colored solution, which presumably contained the diazo-amino compound, deepened in color on standing, gradually depositing the orange monosodiunn salt in good yield. Recrystallized from boiling water containing a little sodium acetate, it forms radiating masses of short, brownish-yellow, microscopic needles which dissolve with difficulty in hot or cold water with an intense orange-yellow color.

Analyses. Calc. for $\mathrm{C}_{14} \mathrm{H}_{13} \mathrm{O}_{5} \mathrm{~N}_{3} \mathrm{AsNa} .2 .5 \mathrm{H}_{2} \mathrm{O}: \mathrm{H}_{2} \mathrm{O}, 10.08$. Found: 10.49 .

Calc. for $\mathrm{C}_{14} \mathrm{H}_{13} \mathrm{O}_{5} \mathrm{~N}_{3} \mathrm{AsNa}$ : N, 10.47. Found: 10.53 .

Treated in a little water with one mol. of sodium hydroxide, then with alcohol to initial turbidity, the disodium salt separated in the cold. It forms bundles of flat, red, microscopic needles from $70 \%$ alcohol and dissolves readily in water with a deep orange color.

Analyses. Calc. for $\mathrm{C}_{14} \mathrm{H}_{12} \mathrm{O}_{5} \mathrm{~N}_{3} \mathrm{AsNa}_{2} .85 \mathrm{H}_{2} \mathrm{O}: \mathrm{H}_{2} \mathrm{O}, 26.57$. Found: 26.63 .

Calc. for $\mathrm{C}_{14} \mathrm{H}_{12} \mathrm{O}_{6} \mathrm{~N}_{3} \mathrm{AsNa}_{2}: \mathrm{N}, 9.93$. Found: $\mathrm{N}, 9.83$.

The monosodium salt, suspended in hot water, dissolved with a little sodium hydroxide, and treated with hydrochloric acid until just acid to congo red, gave the free acid, which when recrystallized from $50 \%$ alcohol forms brick-red, thin, glistening microscopic needles and plates. It does not melt below $280^{\circ}$ dissolves in conc. sulfuric acid with a deep orange color and gives a red solution in hot $10 \%$ hydrochloric acid, from which the hydrochloride separates on cooling as rosets of narrow, purplish-red plates with a steel-blue reflex. In dil. hydrochloric acid the dye reacts with sodium nitrite, giving a precipitate of pale salmon-colored, microscopic needles, presumably the nitroso compound.

Analyses. Calc. for $\mathrm{C}_{14} \mathrm{H}_{14} \mathrm{O}_{5} \mathrm{~N}_{8} \mathrm{As}$ : N, 11.08; As, 19.78. Found: $\mathrm{N}, 11.24$; As, 19.68 .

4 - Ethylamino - 5 - carboxy-phenylazo-benzene-4'-arsonic acid.-B $\rightarrow$ A. -The crude monosodium salt was dissolved in hot water with a little sodium hydroxide and 
the solution just acidified to congo red, yielding the bright yellow arsonic acid. It separates from $85 \%$ alcohol as deep orange, glistening rectangular platelets which do not melt below $275^{\circ}$. It is more soluble in methyl alcohol or boiling amyl alcohol than in the other usual neutral solvent:s, and in its color reactions and chemical properties resembles the methylamino compound.

Analyses. Calc. for $\mathrm{C}_{15} \mathrm{H}_{16} \mathrm{O}_{5} \mathrm{~N}_{3} \mathrm{As}$; N, 10.69 ; As, 19.06. Found: N, 10.72 As, 19.11 .

4 - Iso-amyl-amino - 5 - carboxy-phenylazo-benzene-4' -arsonic acid.-B $\longrightarrow$ A.The crude monosodium salt when recrystallized from much water containing a little sodium acetate forms orange-colored, microscopic leaflets which are very difficultly soluble in boiling water.

Analyses. Calc. for $\mathrm{C}_{18} \mathrm{H}_{21} \mathrm{O}_{5} \mathrm{~N}_{3} \mathrm{AsNa} \cdot 2 \mathrm{H}_{2} \mathrm{O}: \mathrm{H}_{2} \mathrm{O}, 7.31$. Found: 6.59

Calc. for $\mathrm{C}_{18} \mathrm{H}_{21} \mathrm{O}_{5} \mathrm{~N}_{3} \mathrm{AsNa}: \mathrm{N}, 9.19$. Found: 9.18 .

Recrystallized from acetic acid, the free acid forms orange-red, glistening, striated platelets which do not melt below $275^{\circ}$. It dissolves in boiling alcohol and gives a deep red-orange color with conc. sulfuric acid; in conc. hydrochloric acid it dissolves with a deep red color, the hydrochloride separating on rubbing as dark colored microscopic needles.

Analyses. Calc. for $\mathrm{C}_{18} \mathrm{H}_{22} \mathrm{O}_{5} \mathrm{~N}_{3} \mathrm{As}: \mathrm{N}, 9.66 ; \mathrm{As}, 17.22$. Found: N, $9.48 ; \mathrm{As}, 17.32$.

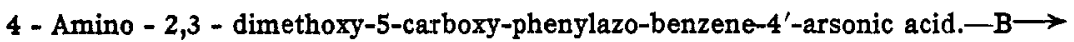
A.-Using vicinal aminoveratric acid, the monosodium salt was obtained, separating as flat, brown-orange, microscopic needles from hot water containing a little sodium acetate.

Analyses. Calc. for $\mathrm{C}_{15} \mathrm{H}_{15} \mathrm{O}_{7} \mathrm{~N}_{3} \mathrm{AsNa} .2 .5 \mathrm{H}_{2} \mathrm{O}: \mathrm{H}_{2} \mathrm{O}, 9.15$. Found: 9.79 .

Calc. for $\mathrm{C}_{15} \mathrm{H}_{15} \mathrm{O}_{7} \mathrm{~N}_{3} \mathrm{AsNa}$ : $\mathrm{N}, 9.40$; As, 16.77 . Found: $\mathrm{N}, 9.76$; As, 16.54 .

The free acid separates from $85 \%$ alcohol as long, narrow, glistening, orange-red platelets which turn a deeper red when anhydrous, but do not melt below $275^{\circ}$. It is quite easily soluble in cold methyl alcohol and gives a deep orange-colored solution in conc. sulfuric acid, dissolving in boiling $10 \%$ hydrochloric acid with a dark red color, depositing the hydrochloride on cooling as brown platelets and flat needles.

Analyses. Calc. for $\mathrm{C}_{15} \mathrm{H}_{16} \mathrm{O}_{7} \mathrm{~N}_{3}$ As. $1.5 \mathrm{H}_{2} \mathrm{O}: \mathrm{H}_{2} \mathrm{O}, 5.98$. Found: 6.43 .

Calc. for $\mathrm{C}_{15} \mathrm{H}_{16} \mathrm{O}_{7} \mathrm{~N}_{3}$ As: As, 17.62. Found: As, 17.78 .

2 - Amino - 4,5 - dimethoxy-3-carboxy-phenylazo-benzene-4'-arsonic acid.-(BA.-Alkalinity sufficient for formation of the disodium salt.) 6-Amino-o-veratric acid ${ }^{5}$ was used. After 24 hours about $20 \%$ of solid soduim acetate was added and then an excess of acetic acid, precipitating the monosodium salt. Recrystallized from water containing sodium acetate, cautiously adding acetic acid after cooling, the salt forms spherules of orange-red microcrystals which change to chocolate-brown when air-dry. It is very difficultly soluble in boilingwater and dissolves on adding alkali with an orange color.

Analyses. Calc, for $\mathrm{C}_{15} \mathrm{H}_{15} \mathrm{O}_{7} \mathrm{~N}_{3} .4 \mathrm{sNa} .1 .5 \mathrm{H}_{2} \mathrm{O}: \mathrm{H}_{2} \mathrm{O}, 5.70$. Found: 6.37 .

Calc. for $\mathrm{C}_{15} \mathrm{H}_{10} \mathrm{O}_{7} \mathrm{~N}_{8} \mathrm{AsNa} ; \mathrm{N}, 9.40 ; \mathrm{As}, 16.77$. Found: N, 9.21; As, 16.65 .

The free acid separates from an alkaline solution of the salt in $50 \%$ alcohol on acidifying to congo red as glistening brown leaflets and microcrystalling aggregates with a purplish luster, containing about 1.5 molecules of water of crystallization and turning darker brown when dehydrated. It decomposes somewhat on heating, but does not melt up to $290^{\circ}$. It is difficultly soluble in the usual solvents, and unlike the monosodium salt, dissolves in dil. alkalies with a red color, only changing to orange at high dilution. It gives an intense red color in conc. sulfuric acid, and dissolves partially in conc. hydro-

5 This acid was prepared by the following series of reactions, which will be dealt with in a later communication: 0 -vanillin $\longrightarrow 0$-veratric aldehyde $\rightarrow 6$-nitro- 0 -veratric aldehyde $\longrightarrow$ 6-nitro-o-veratric acid $\longrightarrow$ 6-amino-o-veratric acid. 
chloric acid, the bydrochloride soon separating as dark orange-red microcrystalline spherules.

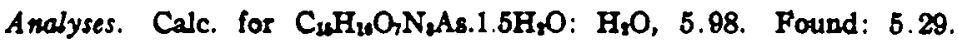

Calc. for $\mathrm{C}_{14} \mathrm{H}_{10} \mathrm{O}_{7} \mathrm{~N}_{2}$ As: $\mathrm{N}, 9.89$. Found: 9.69 .

\section{(C) Dyes Derived from Arsanilic Acid and Aromatic Glycines.}

4-Phenyl-(4'-arsonic acid) azo]-phenglgitycine.-Although phenylglycine yielded the diazo-amino compound under the conditions given in the preceding paper, the dye was formed in the presence of an excess of mineral acid. The diazo solution from $4.4 \mathrm{~g}$. of arsanilic acid was added, with stirring and chilling, to a solution of 3.1 g. of phenylglycine in $40 \mathrm{cc}$. of $N$ hydrochloric acid diluted to $100 \mathrm{cc}$. with $0.5 \mathrm{~N}$ hydrochloric acid. The dye, which crystallized soon after deposition commenced, was filtered off, washed first with cold and then with hot water, and was finally cooled and washed with acetane. The yield was $5.3 \mathrm{~g}$. A dilute solution in $50 \%$ alcohol was obtained with the aid of a little ammonia and acidified hot to congo red, the arsonic acid soos separating as orange-red aggregates of minute, lenticular platelets with a golden luster. It sinters, melts, and decomposes slowly at $170-5^{\circ}$, and dissolves in dil. alkali with a reddish-orange color. It dissolves in conc. sulfuric acid or $1: 1$ hydrochloric acid with a deep red color, the hydrochloride separating from the latter on rubbing as red microscopic needles with a purplish luster.

A nalyses. Calc. for $\mathrm{C}_{4} \mathrm{H}_{14} \mathrm{O}_{3} \mathrm{~N}_{1}$ As. $0.5 \mathrm{H}_{2} \mathrm{O}: \mathrm{H}_{2} \mathrm{O}, 2.32$. Found: 2.86 .

Calc. for $\mathrm{C}_{14} \mathrm{H}_{14} \mathrm{O}_{6} \mathrm{~N}_{4}$ As: $\mathrm{N}, 11.07$. Found: 11.43 .

2 - Methyl - 4 - [phenjt - (4'-arsonic acid) azo] phenglgtycine.-(A unneutralized $\longrightarrow B$ in 2 mols. of alkali.) The dye salt separated on rubbing and was dissolved in $50 \%$ alcohol with the aid of sodium hydroxide and the red-orange solution then made just acid to congo red, the arsonic acid separating as red-brown needles, leatlets, and rhombic platelets. When rapidly heated to $155^{\circ}$, then slowly, the acid rediens and intumesces at $157^{\circ}$. It is quite soluble in the cold in methyl alcohol, and dissolves in conc. sulfuric acid with a deep red color. A solution in $1: 1$ hydrochloric acid deposits the hydrochloride on rubbing as minute, dark brown platelets with a purple luster.

Analyses. Calc. for $\mathrm{C}_{15} \mathrm{H}_{16} \mathrm{O}_{6} \mathrm{~N}_{2}$ As. $\mathrm{H}_{2} \mathrm{O}: \mathrm{H}_{3} \mathrm{O}, 4.38$. Found: 3.49 .

Calc. for $\mathrm{C}_{16} \mathrm{H}_{16} \mathrm{O}_{5} \mathrm{~N}_{1} \mathrm{As}$ : N, 10.69; As, 19.06 . Found: N, 10.70; As, 19.08 .

2 - Methory - 4 - [phenyl - (4'-arsonic acid) azo] phenytiftctne.-(B in 1 mol. of alkali $\longrightarrow$ A treated with one mol. of alkali and saturated with salt.) The mortosodium salt gradually crystallized. It separates from dil. aqueous alcoholic altrali on adding acetic acid as very thin, nacreous, orange-red platelets containing about 2.5 molecules of water of crystallization when air-dry and dissolving in water with a deep red color, changing to brown and depositing microcrystalline spherules of what appears to be a different hydrate; on adding sodium acetate or sodium hydroxide a clear, deep orange solution results.

Analyses. Calc. for $\mathrm{C}_{16} \mathrm{H}_{15} \mathrm{O}_{6} \mathrm{~N}_{3} \mathrm{AsNa} .2 .5 \mathrm{H}_{2} \mathrm{O}: \mathrm{H}_{2} \mathrm{O}, 9.46$. Found: 8.93 .

Calc. for $\mathrm{C}_{16} \mathrm{H}_{16} \mathrm{O}_{6} \mathrm{~N}_{2} \mathrm{AsNa}$; As, 17.39. Found: 17.28.

The acid was obtained in the usual way as minute, glistening, steel-blue aggregates of platelets. When rapidly heated the air-dry acid melts and effervesces at about $160^{\circ}$. but if dried first it gradually reddens on heating and intumesces at $167^{\circ}$ to a blood-red mass. It is quite soluble in the cold in methyl alcohol, easily in hot ethyl alcohol, and dissolves in conc. sulfuric acid with a deep purple color, in $1: 1$ bydrochloric acid with a deep red color, and in dil. solutions of carbonates or alkalies with an orange color.

Analyses. Calc. for $\mathrm{C}_{16} \mathrm{H}_{36} \mathrm{O}_{6} \mathrm{~N}_{2} \mathrm{As} .15 \mathrm{H}_{2} \mathrm{O}: \mathrm{H}_{2} \mathrm{O}, 6.19$. Found: 6.11 .

Calc. for $\mathrm{C}_{16} \mathrm{H}_{16} \mathrm{O}_{6} \mathrm{~N}_{2} \mathrm{As}: \mathrm{N}, 10.27$. Found: $\mathrm{N}, 10.30$.

2 - Ethoxy - 4- [phenyl - (4'-arsonic scid) azol phenjldycino.-On adding an equal volume of saturated sodiam chloride solution to the turbined reaction misture 
the monosodium salt separated as a paste, but crystallized on rubbing. From $50 \%$ alcohol it forms rosets of orange-brown, glistening platelets which dissolve in water with a brown-red color.

Analyses. Calc. for $\mathrm{C}_{16} \mathrm{H}_{17} \mathrm{O}_{6} \mathrm{~N}_{3} \mathrm{AsNa} .25 \mathrm{H}_{2} \mathrm{O}: \mathrm{H}_{2} \mathrm{O}, 9.19$. Found: 8.68.

Calc. for $\mathrm{C}_{16} \mathrm{H}_{17} \mathrm{O}_{6} \mathrm{~N}_{3} \mathrm{AsNa}$ : N, 9.44. Found: 9.63 .

The free acid separates very incompletely as rosets and sheaves of flat, purplishbrown, microscopic needles which decompose at $245-50^{\circ}$ and are freely soluble in $50 \%$ alcohol and $50 \%$ acetic acid, especially on warming. The solution in conc. sulfuric acid is deep red, appearing purple in thin layers.

Analysis. Calc. for $\mathrm{C}_{16} \mathrm{H}_{18} \mathrm{O}_{6} \mathrm{~N}_{3} \mathrm{As}: \mathrm{N}, 9.93$. Found: 10.12 .

$\alpha^{\prime}$ - [Phenyl - (4-arsonic acid) azo] $-\alpha-$ naphthylglycine.-The monosodiun salt was precipitated from the reaction mixture with an equal volume of alcohol, converted into the disodium salt by dissolving in one molecular equivalent of sodium hydroxide and adding alcohol until precipitation began, purifying by redissolving in warm $50 \%$ alcohol and treating with alcohol until the concentration of solvent was about $85 \%$, whereupon the salt crystallized. It dissolves readily in water with a purple color.

Analyses. Calc. for $\mathrm{C}_{18} \mathrm{H}_{14} \mathrm{O}_{5} \mathrm{~N}_{3} A_{\mathrm{LSNa}}: \mathrm{N}, 8.88 ; \mathrm{As}, 15.85$. Found: $\mathrm{N}, 9.00$; As, 15.36.

The salt was dissolved in $25 \%$ alcohol, made just acid to congo red, and filtered at once from a trace of amorphous matter, after which the free acid soon crystallized. It melts and decomposes at about $275^{\circ}$ with preliminary darkening and softening and dissolves in conc. sulfuric acid with a deep red color, appearing purple in thin layers.

Analyses. Calc. for $\mathrm{C}_{18} \mathrm{H}_{16} \mathrm{O}_{5} \mathrm{~N}_{3}$ A.s. $0.5 \mathrm{H}_{2} \mathrm{O}: \mathrm{H}_{2} \mathrm{O}, 2.1$. Found: 3.0 .

Calc. for $\mathrm{C}_{18} \mathrm{H}_{16} \mathrm{O}_{5} \mathrm{~N}_{3} \mathrm{As}: \mathrm{N}, 9.79$. Found: 9.48 .

\section{(D) Dyes Derived from Arsanilic Acid and Aromatic $N$-Methyl Sul- fonic Acids.}

4 - [Phenyl - (4'-arsonic acid) azo] - phenyl-aminomethyl sulfonic acid, $\mathrm{H}_{2} \mathrm{O}_{2} \mathrm{AsC}_{6}$ $\mathrm{H}_{4} \mathrm{~N}: \mathrm{NC}_{6} \mathrm{H}_{4} \mathrm{NHCH}_{2} \mathrm{SO}_{3} \mathrm{H}$.-Methylene-aniline sodium bisulfite solution was added to neutralized A saturated with salt. The disodinm salt of the dye soon began to crystallize on keeping in the cold, and the process was hastened by the addition of two-thirds of a volume of saturated sodium acetate solution. Recrystallized from 50\% alcohol, the salt separates as delicate, orange-colored needles which dissolve readily in water.

Analyses. Calc. for $\mathrm{C}_{13} \mathrm{H}_{12} \mathrm{O}_{6} \mathrm{~N}_{3} \mathrm{SAsNa}_{2} .4 .5 \mathrm{H}_{2} \mathrm{O}: \mathrm{H}_{2} \mathrm{O}, 15.01$. Found: 15.09 .

Calc. for $\mathrm{C}_{13} \mathrm{H}_{12} \mathrm{O}_{6} \mathrm{~N}_{8} \mathrm{SAsNa}_{2}: \mathrm{N}, 9.15 ; \mathrm{As}, 16.32$. Found: $\mathrm{N}, 9.63 ; \mathrm{As}, 16.78$.

The salt was dissolved in $25 \%$ alcohol and the solution acidified tocongo red. The acid soon separated as sheaves of minute, flat, red needles with a purplish reflex. It dissolves with difficulty in cold water, readily on boiling, with a red color. When rapidly heated to $185^{\circ}$, then slowly, the anhydrous acid turns bright red, then sinters, and finally swells and melts partially at $187-9^{\circ}$. It dissolves in conc. sulfuric acid with a transient, deep orange color, quickly fading to yellow.

Analyses. Calc. for $\mathrm{C}_{13} \mathrm{H}_{14} \mathrm{O}_{6} \mathrm{~N}_{3} \mathrm{siAs} .2 \mathrm{H}_{2} \mathrm{O}: \mathrm{H}_{2} \mathrm{O}, 7.99$. Found: 8.23.

Calc. for $\mathrm{C}_{13} \mathrm{H}_{14} \mathrm{O}_{6} \mathrm{~N}_{3} \mathrm{SAs}: \mathrm{N}, 10.12 ; \mathrm{As}, 18.05$. Found: $\mathrm{N}, 10.30 ; \mathrm{As}, 18.25$.

2 - Methoxy - 4 - [phenyl - (4'-arsonic acid) azo] - phenyl-aminomethyl sulfonic acid.-As in the preceding case, methylene- 0 -anisidine sodium bisulfite yielded a disodium salt which was dissolved in a small volume of water and treated cautiously with somewhat more than an equal volume of alcohol. On standing in the cold, the salt separated as orange-red, microscopic needles dissolving readily in water with a deep orange-red color.

Analyses. Calc. for $\mathrm{C}_{14} \mathrm{H}_{14} \mathrm{O}_{7} \mathrm{~N}: \mathrm{SAsNa}_{2} 3 \mathrm{H}_{2} \mathrm{O}: \mathrm{H}_{2} \mathrm{O}, 9.95$. Found: 9.96.

Calc. for $\mathrm{C}_{14} \mathrm{H}_{14} \mathrm{O}_{7} \mathrm{~N}_{3} \mathrm{SAsNa}_{2}$ : As, 15.32. Found: 15.52 . 
In $50 \%$ alcohol, mineral acid causes the free arsonic acid to separate as lustrous, flat, violet needles. The anhydrous acid reddens and softems above $155^{\circ}$, and melts with slow gas evolution at $158-60^{\circ}$, dissolving in conc. sulfuric acid with a deep purple color which changes to deep red on standing.

A nalyses. Calc. for $\mathrm{C}_{14} \mathrm{H}_{16} \mathrm{O}_{7} \mathrm{~N}_{2} \mathrm{SAs} .1 .5 \mathrm{H}_{2} \mathrm{O}: \mathrm{H}_{2} \mathrm{O}, 5.72$. Found: 4.85 .

Calc. for $\mathrm{C}_{14} \mathrm{H}_{18} \mathrm{O}_{7} \mathrm{~N}_{2} \mathrm{SAs}: \mathrm{N}, 9.44$. Found: 9.28 .

\section{(E) Dyes Derived from Arsanilic Acid and Substituted Phenoxyacetic Acids.}

3 - Amino - 6 - [phenjl - (4'-arsonic acid) azo] - phenoryacetic acid, $\mathrm{H}_{2} \mathrm{O}_{2} \mathrm{AsC}$ $\mathrm{H}_{4} \mathrm{~N}: \mathrm{NC}_{6} \mathrm{H}_{3}\left(\mathrm{NH}_{2}\right) \mathrm{OCH}_{2} \mathrm{CO}_{2} \mathrm{H}$. - m-Amino-phenoxyacetic acid' yielded a deep red solution which was gently warmed and treated with alcohol, depositing the orange microcrystalline monosodium salt, which was converted into the acid by dissolving in a considerable volume of dilute alcohol with the aid of sodium hydroxide and making the solution just acid to congo red. The acid separated as red, glistening needles. When anhydrous it blackens, but does not melt below $285^{\circ}$, dissolving in conc. sulfuric acid with an orange-red color, in dil. alkalies with an orange color, and gives an orange-red color in 1:1 hydrochloric acid, the hydrochloride separating on rubbing as orange-brown microscopic crystals.

Analyses. Calc. for $\mathrm{C}_{14} \mathrm{H}_{14} \mathrm{O}_{6} \mathrm{~N}_{2} \mathrm{As} .15 \mathrm{H}_{2} \mathrm{O}: \mathrm{H}_{2} \mathrm{O}, 6.40$. Found: 6.99.

Calc. for $\mathrm{C}_{16} \mathrm{H}_{14} \mathrm{O}_{6} \mathrm{~N}_{2}$ As: $\mathrm{N}, 10.63$; As, 18.96. Found: $\mathrm{N}, 10.74 ;$ As, 18.75.

4 - Methyl - 3 - amino - 6 - [phenyl - (4'-arsonic acid) azo] - phenoxyacetic acid4-Methyl-5-amino phenoxyacetic acid'gave the monosodium salt of the dye as a red, crystalline mass which was converted as usual into the acid, this separating as dark red aggregates of flat needles with a purple reflex. When rapidly heated to $240^{\circ}$, then slowly, the dye intumesces at $242-3^{\circ}$, with preliminary blackening. It gives an orange color in conc. sulfuric acid or dil. alkalies, and is difficultly soluble in conc. hydrochoric acid, changing on rubbing to an orange-red, microcrystalline hydrochloride.

A nalyses. Calc. for $\mathrm{C}_{15} \mathrm{H}_{16} \mathrm{O}_{6} \mathrm{~N}_{2}$ As. $\mathrm{H}_{3} \mathrm{O}: \mathrm{H}_{2} \mathrm{O}, 4.22$. Found: 3.47 .

Calc. for $\mathrm{C}_{16} \mathrm{H}_{16} \mathrm{O}_{6} \mathrm{~N}_{2} \mathrm{As}: \mathrm{N}, 10.27$ : As, 18.31 . Found: $\mathrm{N}, 10.06$; As, 18.51.

2 - Methyl - 5 - amino - 4 - [phenyl - (4'-arsonic acid) azo] - phenoryacettc acid.In the case of 2-methyl-5-amino-phenoxyacetic acid, ${ }^{7}$ the deep red-brown solution of the monosodium salt was filtered, concentrated partially in vacuo, and allowed to stand in the cold. The resulting crystals were dissolved in boiling $85 \%$ alcohol containing acetic acid, and on cooling the free acid separated. Reprecipitated in $33 \%$ alcohol it forms flat, glistening, purplish-brown needles which dissolve readily in methyl alcohol, less easily in ethyl alcohol. When rapidly heated to $185^{\circ}$, then slowly, it intumesces at $187-8^{\circ}$. It dissolves in conc. sulfuric acid with a deep orange color and partially in conc. hydrochloric acid with a red shade, soon depositing the hydrochloride as dull red microcrystals.

Analyses. Calc. for $\mathrm{C}_{16} \mathrm{H}_{10} \mathrm{O}_{6} \mathrm{~N}_{2} \mathrm{As} .2 \mathrm{H}_{2} \mathrm{O}: \mathrm{H}_{2} \mathrm{O}, 8.09$. Found: 7.07.

Calc. for $\mathrm{C}_{16} \mathrm{H}_{10} \mathrm{O}_{6} \mathrm{~N}_{2}$ As: $\mathrm{N}, 10.27$. Found: 10.38 .

3 - Amino - 6 - methory - 4 - [ phengl - (s'-arsonic acid) azo] - phenoryacetic acid Precipitation of the dye acid obtained from 3-amino-6-methoxy-phenoryacetic acid was facilitated by the addition of acetic acid and the collected product was dissolved in dil. sodium hydroxide, filtered, and reprecipitated with an excess of acetic acid. Reprecipitated in $50 \%$ alcohol, the acid separates as flat, glistening, bronze needles and platelets. The air $\mathrm{dry}$ acid sinters, softens, and swells at $175-85^{\circ}$, while the anhydrous substance intumesces at $208-13^{\circ}$ with preliminary sintering and softening. It dissolves

- Tris Journal, 39, 2912 (1917).

${ }^{7}$ Ibid., 39, 2193 (1917).

- Loc. cit., p. 2194. 
appreciably in the cold in methyl or ethyl alcohol, readily on warming, and dissolves in dil. alkalies or cärbonates with an orange-red color. It gives a bright red color in conc. sulfuric acid and yields a deep purplish-red solution in $1: 1$ hydrochloric acid, almost immediately depositing the hydrochloride as dark brown, microscopic platelets.

Analyses. Calc. for $\mathrm{C}_{13} \mathrm{H}_{16} \mathrm{O}_{7} \mathrm{~N}_{3} \mathrm{As} .45 \mathrm{H}_{2} \mathrm{O}: \mathrm{H}_{2} \mathrm{O}, 16.02$. Found: 15.47 .

Calc. for $\mathrm{C}_{15} \mathrm{H}_{16} \mathrm{O}_{7} \mathrm{~N}_{3} \mathrm{As}: \mathrm{N}, 9.88$. As, 17.64 . Found: $\mathrm{N}, 9.89 ; \mathrm{As}, 17.62$.

4 - Amino - 6 - methoxy - 3 - [ phenyl - (4' - arsonic acid) azo] - phenoxyacetic acid.Using 4-amino-6-methoxy-phenoxyacetic acid, ${ }^{9}$ the monosodium salt of the dye gradually separated, best on concentrating to smaller bulk in vacuo and allowing to stand in the ice box. Recrystallized from dil. sodium acetate solution, it separates as chocolate colored, microscopic needles which are very sparingly soluble in water, but dissolve on adding carbonate or alkali with a dark red color.

Analyses. Calc. for $\mathrm{C}_{15} \mathrm{H}_{15} \mathrm{O}_{7} \mathrm{~N}_{3} \mathrm{AsNa} 65 \mathrm{H}_{2} \mathrm{O}: \mathrm{H}_{2} \mathrm{O}, 20.75$. Found: 21.03 .

Calc. for $\mathrm{C}_{15} \mathrm{H}_{15} \mathrm{O}_{7} \mathrm{~N}_{3} \mathrm{AsNa}$ : As, 16.77. Found: 16.31 .

The free acid can be precipitated in $50 \%$ alcohol as minute, glistening, maroon platelets. It does not melt below $280^{\circ}$, and dissolves in conc. sulfuric acid with a bright red color. A solution in hot 1:1 hydrochloric acid deposits the hydrochloride on cooling as dark red, flat needles.

Analyses. Calc. for $\mathrm{C}_{16} \mathrm{H}_{16} \mathrm{O}_{7} \mathrm{~N}_{3}$ As. $2 \mathrm{H}_{2} \mathrm{O}: \mathrm{H}_{2} \mathrm{O}, 7.81$. Found: 7.89 .

Calc. for $\mathrm{C}_{16} \mathrm{H}_{16} \mathrm{O}_{7} \mathrm{~N}_{3} \mathrm{As}: \mathrm{N}, 9.89$. Found: 9.97 .

4 - Amino - 5 - [phenyl - (4' - arsonic acid) azo] - 1,2-bis-phenoxyacetic acid.-A $\longrightarrow$ B, using 4-amino-1,2-bis-phenoxyacetic acid. ${ }^{10}$ After acidifying with acetic acid the monosodium salt of the dye separated as dark purplish-brown, microcrystalline spherules. It is very sparingly soluble in water, but dissolves with an orange-red color on adding carbonate or alkali.

Analyses. Calc. for $\mathrm{C}_{16} \mathrm{H}_{15} \mathrm{O}_{9} \mathrm{~N}_{3}$ As.Na.4.5 $\mathrm{H}_{2} \mathrm{O}: \mathrm{H}_{2} \mathrm{O}, 14.17$. Found: 14.40 .

Calc. for $\mathrm{C}_{16} \mathrm{H}_{15} \mathrm{O}_{9} \mathrm{~N}_{3} \mathrm{AsNa}: \mathrm{N}, 8.56$. Found: 8.61.

When precipitated in much warm $50 \%$ alcohol, deposition of amorphous material is prevented and the free acid separates as dark purplish-brown microcrystals. Its repetition of this process was necessary before the acid was analytically pure. A dissolves in conc. sulfuric acid with an orange-red color, and when anhydrous, softens and sinters when heated, but does not melt below $280^{\circ}$.

Analyses. Calc. for $\mathrm{C}_{16} \mathrm{H}_{16} \mathrm{O}_{9} \mathrm{~N}_{3}$ As. $3 \mathrm{H}_{2} \mathrm{O}: \mathrm{H}_{2} \mathrm{O}, 10.33$. Found: 10.58 .

Calc. for $\mathrm{C}_{16} \mathrm{H}_{16} \mathrm{O}_{2} \mathrm{~N}_{3} \mathrm{As}$ : $\mathrm{N}, 8.96$. As, 15.97. Found: $\mathrm{N}, 9.07$; As, 15.8 .

$\alpha$-Amino- $\beta$-[phenyl-(4-arsonic acid)] azo - $\alpha^{\prime}$-naphthoxyacetic acid.$\alpha$-Amino- $\alpha^{\prime}$-naphthoxyacetic acid" ${ }^{11}$ gave a deep purple, amorphous precipitate which was dissolved by adding $1 \mathrm{~mol}$. of sodum hydroxide and the solution treated with several volumes of alcohol, causing deposition of the disodium salt. Recrystallized from $50 \%$ alcohol, it separates as dark brown, felted microscopic needles which dissolve readily in water with a dark purplish-red color.

Analyses. Calc. for $\mathrm{C}_{18} \mathrm{H}_{14} \mathrm{O}_{6} \mathrm{~N}_{3} \mathrm{AsNa}_{2} .9 \mathrm{H}_{2} \mathrm{O}: \mathrm{H}_{2} \mathrm{O}, 24.89$. Found: 25.25 .

Calc. for $\mathrm{C}_{15} \mathrm{H}_{14} \mathrm{O}_{6} \mathrm{~N}_{3} \mathrm{AsNa}_{2}: \mathrm{N}, 8.59 ; \mathrm{As}, 15.33$. Found: $\mathrm{N}, 8.46 ; \mathrm{As}, 15.71$.

The free acid may be precipitated in much warm $50 \%$ alcohol as flat, dark red needles with a golden luster. It decomposes at about $285^{\circ}$, with preliminary darkening and softening. It dissolves in conc. sulfuric acid with a deep purplish-red color.

Analysis. Calc. for $\mathrm{C}_{18} \mathrm{H}_{16} \mathrm{O}_{6} \mathrm{~N}_{3}$ As: N, 9.44. Found: 9.47 .

$\alpha$-Amino - $\alpha^{\prime}$ - [phenyl - (4-arsonic acid)] azo- - $\beta$-naphthoxyacetic acid.-Sodium salt of $\alpha$-amino- $\beta$-naphthoxyacetic acid $\rightarrow$ neutralized $A$. The deep purple solution was concentrated to small bulk in vacuo and treated with several volumes of alcohol.

- Loc. cit., p. 2212.

${ }^{10}$ Ibid., p. 2216.

${ }^{11}$ Ibid., p. 2217. 
the disodium salt separating in the cold. Recrystallized from $50 \%$ alcohol it forms almost black aggregates of microscopic hairs with a greenish reflex and dissolving in water with a deep red color.

Analyses. Calc. for $\mathrm{C}_{18} \mathrm{H}_{14} \mathrm{O}_{6} \mathrm{~N}_{3} \mathrm{AsNa}_{2} .8 .5 \mathrm{H}_{2} \mathrm{O}: \mathrm{H}_{2} \mathrm{O}, 23.84$. Found: 23.64 .

Calc. for $\mathrm{C}_{18} \mathrm{H}_{14} \mathrm{O}_{6} \mathrm{~N}_{3} \mathrm{AsNa}_{2}: \mathrm{N}, 8.59 ; \mathrm{As}, 15.33$. Found: $\mathrm{N}, 8.56 ; \mathrm{As}, 15.81$.

The free acid, when liberated in much $50 \%$ alcohol slowly separates as red-brown microcrystalline aggregates which do not melt below $285^{\circ}$.

Analyses. Calc. for $\mathrm{C}_{18} \mathrm{H}_{16} \mathrm{O}_{6} \mathrm{~N}_{2} \mathrm{As} \cdot \mathrm{H}_{2} \mathrm{O}: \mathrm{H}_{2} \mathrm{O}, 3.89$, Found: 3.96 .

Calc. for $\mathrm{C}_{18} \mathrm{H}_{16} \mathrm{O}_{6} \mathrm{~N}_{3} \mathrm{As}: \mathrm{N}, \mathrm{C} .44$. Found: 9.49 .

2 - Hydroxy - 5 - [phenyl - (4'-arsonic acid) azo] - phenoxyacetic acid.-Neutral $A \rightarrow$ alkaline $o$-hydroxy-phenoxyacetic acid solution. The neutralized solution was concentrated to small bulk in vacuo, and the dye precipitated by adding strong sodium hydroxide solution. Dissolved in hot $50 \%$ alcohol and treated with an excess of acetic acid, the monosodium salt separated as yellow, indefinitely crystalline, microscopic globules.

Analyses. Calc. for $\mathrm{C}_{14} \mathrm{H}_{12} \mathrm{O}_{7} \mathrm{~N}_{2} \mathrm{AsNa}: \mathrm{N}, 6.70 ;$ As, 17.93 . Found: $\mathrm{N}, 6.42$; As, 18.33 .

The free arsonic acid separated from a solution in dil. sodium hydroxide as an emulsion which soon crystallized. Dissolved in boiling $85 \%$ alcohol, and the filtrate diluted with water, the acid separated as brown, microscopic platelets which do not melt below $280^{\circ}$. It dissolves in boiling alcohol, and gives a bright orange solution in dil. sodium hydroxide. The color: in conc. sulfuric acid is a deep red-orange.

Analyses. Calc. for $\mathrm{C}_{44} \mathrm{H}_{18} \mathrm{O}_{7} \mathrm{~N}_{2} \mathrm{As} .0 .5 \mathrm{H}_{2} \mathrm{O}: \mathrm{H}_{2} \mathrm{O}, 2.2$. Found: 2.4.

Calc. for $\mathrm{C}_{14} \mathrm{H}_{13} \mathrm{O}_{7} \mathrm{~N}_{2}$ As: $\mathrm{N}, 7.07$; As, 18.92. Found: $\mathrm{N}, 6.99 ;$ As, 18.61 .

NEW YORK, N. Y.

[Contribution from the Gates Chemical laboratory of the Califformia Institute of Technology. No. 7.]

\title{
CHROMO-ISOMERIC SILVER SALTS OF PENTABROMOPHENOL AND A THEORY OF CHROMO-ISOMERISM OF SOLID COMPOUNDS.
}

\author{
By Howard J. Lucas and Archie R. Kemp. \\ Received March 4, 1921.
}

\section{Previous Investigations.}

Two silver salts of pentabromophenol have been described. Bodroux ${ }^{1}$ obtained a rose-colored amorphous precipitate upon adding silver nitrate to a solution of the potassium salt. Hantzsch and Scholtze ${ }^{2}$ also obtained a reddish amorphous precipitate in the same manner, ascribing the color to an impurity present in the pentabromophenol; but they also described a colorless, amorphous form, which precipitates when alcoholic silver nitrate is added to an alcoholic solution of the ammonium salt, and they apparently regard it as a purer lot of the same salt, which they describe as colorless, and existing in only one form. Isomeric silver salts of other

${ }_{1}^{1}$ Bodroux, Compt. rend., 126, 1282-85 (1898).

${ }^{2}$ Hantzsch and Scholtze, Ber', 40, 4882 (1907). 